なほど長時間を要する。これは粒子中におけるイオンの拻散速度

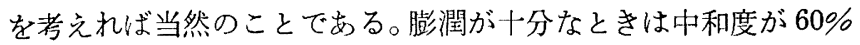
に達すれば液はほと儿ど澄朋となって, 見掛け上水溶液と変わり なく, $\mathrm{pH}$ の時間的変化もほとんど認められなくなる。膨潤が不 十分なときでも中和の進行とともに膨潤度を增し, $\mathrm{pH}$ 值の時間 的变化は次第に小さくなる。しかし, 当量点に近つくくと $\mathrm{pH}$ の時 間的変化が再び認められるようになる。抢とらくこれは微量に混 存する $\mathrm{CO}_{2}{ }^{2-}$ の影響と, 結合の弱い“ラクトン” の開裂に基因す るものと思われる。十分膨潤したアルギン酸粉末の懸濁夜では, たと党ば $\mathrm{N} / 10-\mathrm{NaOH} 1 \mathrm{cc}$ を加え $\mathrm{pH}$ 值が汪涪一定した 3 分後 の $\mathrm{pH} 3.80$ をそのまま約 1 洔間放置すると $\mathrm{pH}$ は 3.58 まで下 がる。しかし前述したような条件で滴定し, ほぼ当量点付近まで 中和したときの $\mathrm{pH} 8.2$ をそのまま約 30 分放置すると $\mathrm{pH}$ は 6.5 まで下がり, 更に $\mathrm{N} / 10-\mathrm{NaOH} 0.1$ cc を追加すると $\mathrm{pH}$ は 再び 8 以上に昇り同じょうな経過をくり返す。このようなことを 何回もくり返していると $\mathrm{pH}$ 值の時間的変化は次第に小となり, 遂に一定值に達する。このときの N/10-NaOH の消費量はほぼ間 接滴定に打ける $\mathrm{N} / 10-\mathrm{NaOH}$ の消費量飞等しくなる。これは初め の当量点付近から “ラクトン” の緩慢な開裂が行われることによ るものと想像される。そして，このときの $\mathrm{pH}$ 值の変化する速度， はアルカリが悡濁粒子の内部に侵入するときの $\mathrm{pH}$ 值の変化する 速度に比較するとはるかに遅い。他方アルギン酸水溶液の滴定に 执いては，滴定過程または滴定後に拔けるこのような $\mathrm{pH}$ 值の時 間的変化は全く認められない。これらの事実もまたアルギン酸粉 末に拈ける“ラクトン”の生成を考皇ることによってよく理解さ れる。

\section{3）“ラクトン” の生成条件}

さて，それではどのような条件で“ラクトン”が生成するであ
ろらか。表 2 は陰陽イオン交換処理を施してつくっだラクトン゙ を生成していないと考兄られるアルギン酸水溶㢈に，アルギン酸 製造工程においてアルギン酸が蒙る種々の条件を与えて“ラクト ン" の生成率 [\{(間接滴定值一直接滴定值)/間接滴定値 $\times 100\}]$ を比較したものである。これによるとアルギン酸水溶液からゲル を生成するような条件では，その方法のいかんを問わす僅かでは， あるが“ラクトン”を生成し，その生成率はいずれる3\% 前後で ある。またメタノールの単独添加は観察しらるよらなゲルの生成 を見ないがやはり同じ程度の “ラクトン”を生成する。ゲル化の ために添加する釷酸の量は “ラクトン” の生成率に影響しないよ ラである。しかし，これらのゲルを乾燥すると“ラクトン”生成 率は急激に增加する。そして乾燥方法にはあまり関係しないらし い。すなわち“ラクトン”の最も生成し易い条件は乾燥にあると 想像される。“ラクトン”の生成が脱水反応であることを考学れ ば，この結果はよく了解される。しかるにアルギン酸水溶液をそ のまま加熱蒸発乾固してつくったフィルムの “ラクトン”生成率 が意外に少ないことは同じ㲦燥処理でありながら興味深いものが ある。技そらく既になんらかの構造をすったゲルを乾燥すること と, 未だなんらの構造をるたない水溶夜を乾燥することとの差異 に基因するものであろう。このことはまた，ペーストを蒸発榦固 してつくったアルギン酸ソーダがアルコール处理によって脱水後 乾燥してつくったものより溶解し易い事実とも関連し，またこの ような例は寒天10)，あるいはゼラチンのような熱可逆性ゲルの溶 解現象においても認められるところであって，高分子電解質に共 通な物性ではないかと想像される。 。

本研究を行らにあたり，御指導いたたいた高橋武雄教授に梁く 感謝致します。

10）高橋，三宅，工化 55，33 (1952).

\title{
塩化ビニル合成の反応速度
}

（昭 和 33 年 7 月 17 日 受 理)

\section{渡辺弘道・小野塚 満男*}

\footnotetext{
アセチレンと塩化水素の気相接触反応による塩化ビニル合成の解析を, 流通式反応管を用いて反応生成物を赤外線分光 分析計に連続的に自記記録し，反応機構を速度論より検討することが出来た。塩化ビニル(VC) 合成反応速度は，原料が ス流速とか触媒粒径等により影響されず，吸着反応物質の表面反応が律速段階であることがわかった。したがって，これ は活性炭に吸着された年コウとアセチレンが反応して 2-クロルビニルマーキュリッククロリドが生成し，それに塩化水 素が反応してVCが合成されるものと考えられる。2 分子吸着物質の表面反応が律速の場合は, Hougen らの理論式によ って, VC 合成反応速度式は

で示されることがわかった。

$$
r=[(1-\chi) /(2-\chi)]^{2} /\left[1.70 \times 10^{-2}-1.94 \times 10^{-2}\{(1-\chi) /(2-\chi)\}\right]^{2} \quad\left(140^{\circ} \mathrm{C}\right)
$$
}

\section{（I）緒 言}

VC は一般にアセチレンと塩化水素を原料とし，年コウを吸着 させた活性炭を触媒とする気相接触反応で合成されている。昇コ ウ自体にアセチレンと塩化水素の混合ガスを通じても VC は合成 されず，昇コウを吸着した活性炭を担体として使用する事により 始めて合成される1)。この VC 合成反応においてトランスおよび

* 只羽化成株式会社錦工場技術部：福島県勿来市錦町.

1) 水谷, 山下, 高分子化学 8, 11, 17, 21 (1951).
シス体の 2-クロルビニルマーキュリッククロリドが年コウとア セチレンの反応により得られるので2，このよ5な中間体を経て 合成されると考えられる。これらのことが活性炭表面でおきてい るのであろろと推定されているだけで反応速度から確認されてい ない。したがってわれわれは，実験室的小型流通反応管を用いて 反応機構を検討し，反応速度の律速段階を明らかにして，気相接 触反応に扣ける見掛け総括反応速度式を求めた。この反応を解析 するには，分析精度が高くかつ触媒の活性能が低下しないうちに

2) Chapman, Jenkins, J. Clw $ミ$ : 15.849 (1919), 
実験を完了する必要があり，短時間で結果が連続的に記録される 自記式赤外線分光分析計を使用した。その結果 VC 合成反応は， 隣接活性坐上の吸着物質相互の表面反応が律速段階であることを 知り, 反応速度を Yang, Watson, Hougen らの理諭式より工業 的に十分満足する見掛け総括反応速度式を得た。

\section{（II） 実 験 方 法}

\section{（1）試 料}

アセチレンは水にカーバイドを投入して発生したアセチレンを 濃硫酸で脱水精製した。塩化水素は $35 \%$ 塩酸を加熱し, 発生ガ ス中の水分を冷凍乾燥して用いた。触媒は活性炭 (5 mm $\phi \times 5$ $\mathrm{mm}$ ）を昇コウ溶液に浸漬し減圧下で加熱乾燥した。吸着升コウ 量は残液中の年コウを青酸カリで滴定して求めた。上記原料ガス の純度は，無機ガス不純物を質量分析計で測定し，そのうち特に 硫化水素，リン化水素については北川式検知管による分析をる併 用した。一方，VC 以外の有機不純物は赤外線分光分析計を用 い，微量のアセトアルデヒドは 2-メテルインドール試薬3を用い て測定した。その結果いずれる $0.01 \%$ (vol) 以下で本実験に十 分な純度であることを確認した。

\section{（2）反応装置}

VC は一般に連続方式で製造されており，したがって実験装置 も流通法を採用した。図 1 に反応装置の略図を示す。ガスホルダ

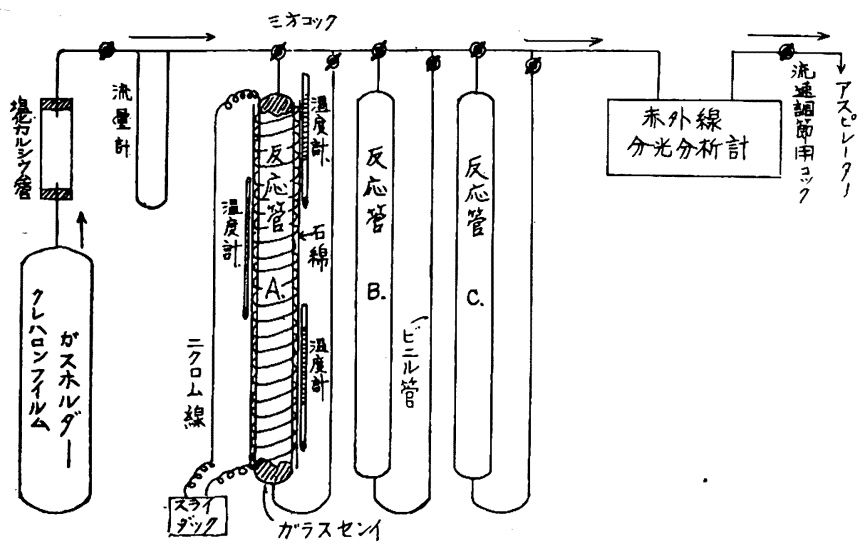

因 1 塩化ビニル合成反応装置

ーには円筒状のクレハロンフィルム（半径 $14 \mathrm{~cm}$, 長さ $5 \mathrm{~m}$ ) を 使用し，この中にほぼ，等モルのアセチレンと塩化水素を入れ， ホルダー出口には誘導爆発防止のために塩化カルシウム管を取り つけた。反応管は長さ約 $80 \mathrm{~cm}$, 内径約 $1.2 \mathrm{~cm}$ の硬質ガラス管 で, 同型のもの 3 個使用し, 直列に使用出来るよ5に接続した。 反応管の内径が小さく，触媒を充填すると内温の測定が困難なの で，反応管加熱用ニクロム線の外側に温度計を取りつけた。反応 管入口にガス流量計オリフィスをつけ，反応管出口と赤外線分光 分析計間をビニル管でつなぎ，ガスセル出口より流速調節用コッ クを経てアスピレーターに連続的にガスを流した。

\section{(3) 測 定 万 法}

混合原料ガスを反応管に流し反応後のガスをパーキンーエルマ 一社製 21 型赤外線分光分析計により連続的に反応率を自記記録 した。ガスセルは食塩板を空とした $5 \mathrm{~cm}$ セルで補償側と 2 個使 用した。測定条件は次のとおりである。

Prism $\mathrm{NaCl}$, Resolution 927, Responce 1-1 Gaine 6
Speed $2 \mathrm{~min} / \mu$, Suppression 6 , 光源電流 0.3 A.

(i) key-band の決定

怪いガス体の浾外線吸仪スベクトルによる定量分惞は，泚合ガ スの成分および種類によってかなり異なる pressure-broadening effect ${ }^{4)}$ (P.B.E) を示す。

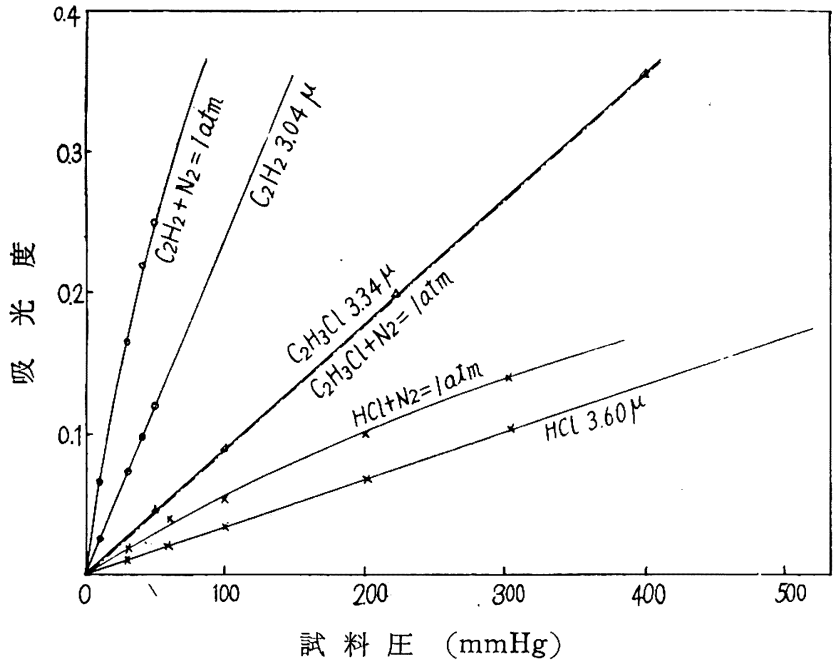

図 2 アセチレン, 塩化水素, 塩化ビニルの P.B.E.

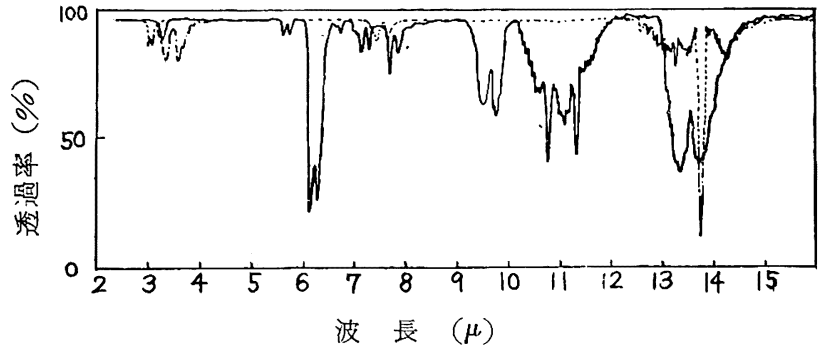

図 $3 \mathrm{~A}$; アセチレン, 塩化水素, 塩化ビニル の梆準スペクトル

$\ldots . . \mathrm{C}_{2} \mathrm{H}_{2}(\mathrm{~g}) \quad-\cdot \mathrm{HCl}(\mathrm{g})-\mathrm{C}_{2} \mathrm{H}_{3} \mathrm{Cl}(\mathrm{g})$

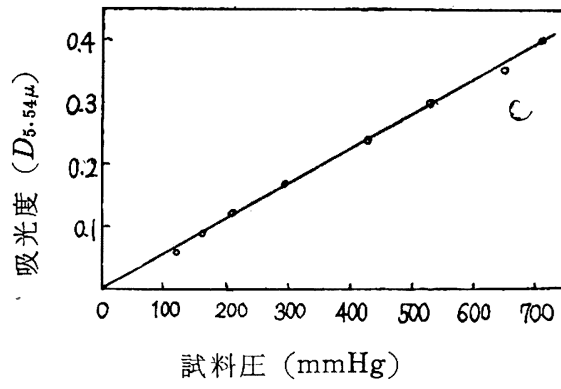

図 $3 \mathrm{~B}$; 塩化ビニルの $5.54 \mu$ に 扣ける㭘量線

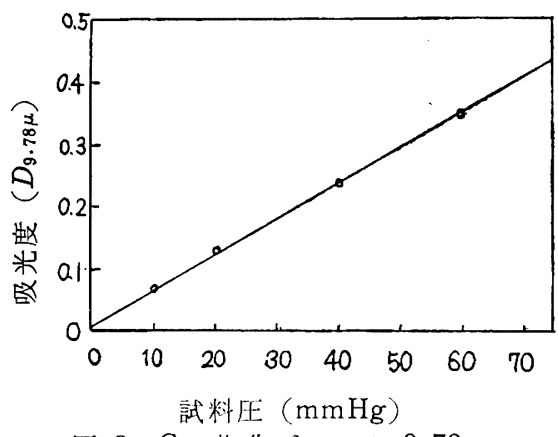

図 $3 \mathrm{C}$; 塩化ビニルの $9.78 \mu$ における検量線
図 2 よりアセチレ ン打よび塩化水素は P.B.E. を示すが $\mathrm{VC}$ は示さないから， 反応率を求めるのに は生成 VC を測定す ることにした。図 3 より未反応アセチレ ン, 塩化水素の吸収 スペクトルの相重 ならない吸収帯で, Beer の法則を満足 する $5.54 \mu$ key一 band とした。低収 率の場合は $9.78 \mu$ の分子吸光俰数の大 きい吸収带をを用い た。
4) N.D. Coggeshall, E. L. Saler, J.Chem. Phys. 15, 65 (1947); J.H. Lee, Ind. Eng. Chem. 18, 659 (1946). 
方法として Hougen, Yang らの)は, 初期反応速度と試料全圧か ら図6のような説明をしている。

この方法にしたがって (iii) (iv) (v) の化学的反応速度の律速 段階を求めた。原料混合ガスを窒素で希釈し，その分圧をかえて 反応率を求めた。この場合の反応条件拉よび結果は表 5 打よび図 7 のと拈りである。

反応条件 反応温度 $140^{\circ} \mathrm{C}$

原料ガス $\mathrm{C}_{2} \mathrm{H}_{2} / \mathrm{HCl}=1 / 1.05$ (モル比)

触 媒 0.17 [g. $\mathrm{HgCl}_{2} / \mathrm{g}$. 活性炭], $15 \mathrm{cc}$ 使用

表 5 原料ガス压と反応率関係

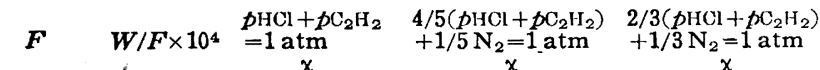

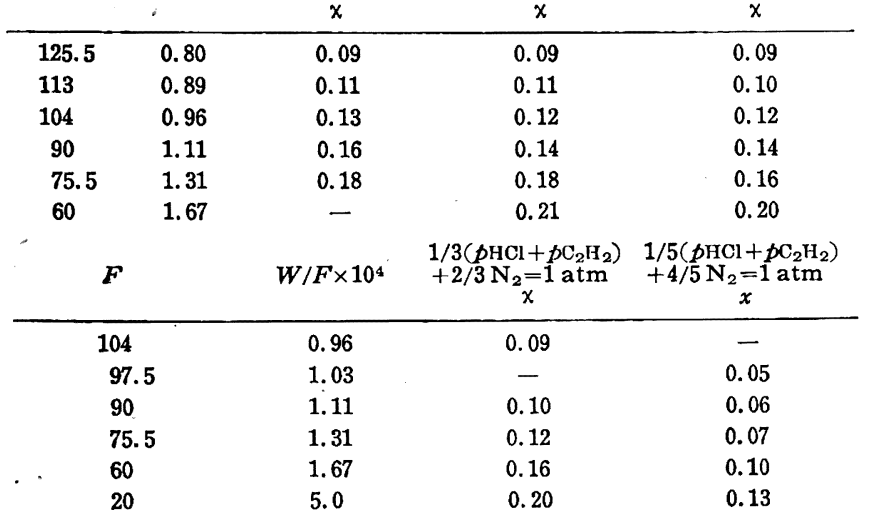

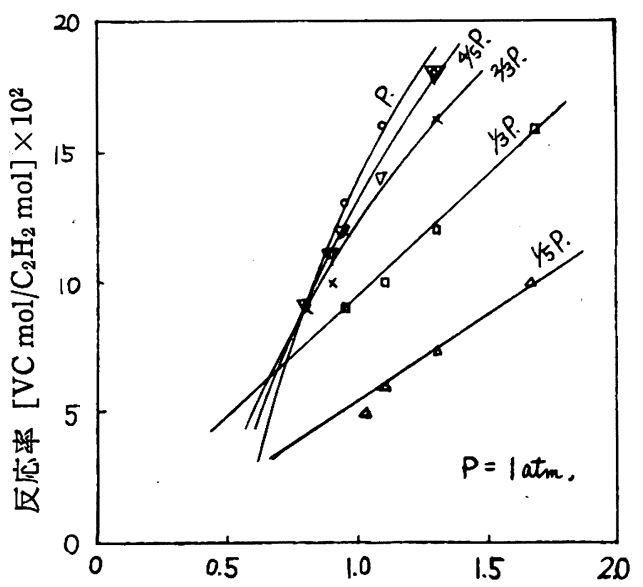

上記結果 より初期反 応速度を反 応率 0 亿外 插して求め 全圧との関 係グラフを 書くと図 8 のようにな り, 図 6 の (A) に相当 ᄂ, 本反応 は隣接活性 座上に吸着 因 7 各原料压に括斿る $W / F$ と反応率の関係 した反応物質の表面反応が律速段階であることがわかった。した がってVC 合成反応は, 活性炭に吸着している年コウとアセチレ ンが反応して中間体をつくり，活性炭に吸着した塩化水素がこれ と表面反応し，活性炭表面から VC が離脱生成するものと考元ら

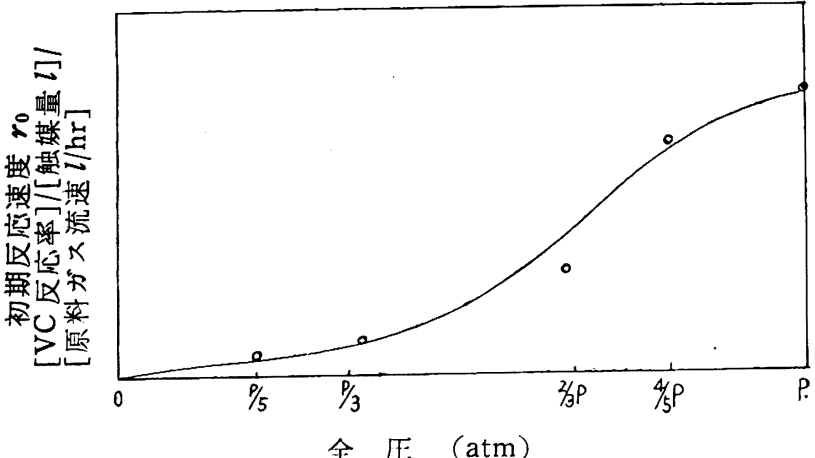

図 8 初期反応速度と全圧との関係
れる。このことはアセチレンと界コウを塩酸酸性のメタノール中 で反応させて得た中間体を活性炭に吸着させると，触媒の活性能 が上がることからも理解出来る。

\section{（2）気相接触反応速度式}

Hougen 57は 2 分子気相接触反応汇批いて，各成分が非解離 の平衡吸着をし，固体触媒上の表面反応が律速である場合には反 応速度式は次の上万に示されると報告している。

反応速度 $=($ 動力学項 $)($ ポテンシァル項 $) /(\text { 吸着項 })^{18}$

$\begin{array}{lll}\text { ポテンシァル項 } & a_{\mathrm{A}} a_{\mathrm{B}}-a_{\mathrm{R}} / \boldsymbol{K} \\ \text { 動 力学 } & \text { 項 } & k_{\mathrm{S} S} S K_{\mathrm{A}} K \mathrm{~B} E_{\mathrm{A}} L \\ \text { 吸 着 } & \text { 項 } & \left(1+K_{\mathrm{A}} a_{\Lambda}+K_{\mathrm{B}} a_{\mathrm{B}}+K_{\mathrm{R}} a_{\mathrm{R}}\right)^{n}\end{array}$

$a$; 気相中の反応物質の活量 $\boldsymbol{K}$; 総括反応の平衡定数

$\mathrm{A} ; \mathrm{B}$; 原料物質 $k_{\mathrm{S}}$; 表面反応速度定数

$\mathrm{R}$; 生成物質 $K$; 吸着平衡定数

$n$; 表面反応に関与する隣接活性夾の数

$E_{\mathrm{A}}$; 触媒の有効係数 $S$; 隣接活性座の数

$L$; 活性吸着來の濃度

したがって VC 合成反応の理論速度式は次のように表わされる。

$$
\begin{array}{r}
r=\left(E_{\mathrm{A}} L k_{\mathrm{S}} S K_{\mathrm{A}} K_{\mathrm{B}}\right)\left(a_{\mathrm{A}} a_{\mathrm{B}}-a_{\mathrm{R}} / \boldsymbol{K}\right) \\
/\left(1+K_{\mathrm{A}} a_{\mathrm{A}}+K_{\mathrm{B}} a_{\mathrm{B}}+K_{\mathrm{R}} a_{\mathrm{R}}\right)^{2}
\end{array}
$$

反応系を理想気体と仮定し活量 $a$ を分圧で示し, 更に $E_{A} \cdot L$. $k_{S} \cdot S \cdot K_{\mathrm{A}} K_{\mathrm{B}}$ を $k$ と置いて (1) 式を書き直すと

$$
\begin{aligned}
r & =k\left(p_{\mathrm{A}} p_{\mathrm{B}}-p_{\mathrm{R}} / \boldsymbol{K}\right) /\left(1+K_{\mathrm{A}} p_{\mathrm{A}}+K_{\mathrm{B}} p_{\mathrm{B}}+K_{\mathrm{R}} p_{\mathrm{R}}\right)^{2} \\
& =\left(p_{\mathrm{A}} p_{\mathrm{B}}-p_{\mathrm{R}} / \boldsymbol{K}\right) /\left(a+b p_{\mathrm{A}}+c p_{\mathrm{B}}+d p_{\mathrm{R}}\right)^{2}
\end{aligned}
$$

ただし $a=1 / \sqrt{k} \quad b=K_{\mathrm{A}} / \sqrt{\bar{k}} \quad c=K_{\mathrm{B}} / \sqrt{k} \quad d=K_{\mathrm{R}} / \sqrt{\bar{k}}$ 原料混合ガスはほぼ等モル使用したのであるから $p_{A}=p_{B}$ とな り上式は次のよう沈なる

$$
\frac{\sqrt{p_{\mathrm{A}}^{2}-\left(1-2 p_{\mathrm{A}}\right) / K}}{r}=(a+d)+(b+c-2 d) p_{\mathrm{A}}
$$

初期反応速度 $p_{R} \fallingdotseq 0$ の時は

$$
p_{\mathrm{A}} / \sqrt{r_{0}}=a+(b+c) p_{\mathrm{A}}
$$

$r$; 反応速度 $\left[\mathrm{VC} \mathrm{mol} / \mathrm{C}_{2} \mathrm{H}_{2} \mathrm{~mol}\right][l$ 原料分入量 $][l \text { 触媒量 }]^{-1}$ $[\mathrm{hr}]^{-1}$

$$
\boldsymbol{K}^{8)}=1.184 \times 10^{7} \quad\left(400^{\circ} \mathrm{K}\right)
$$

$p ;$ 分圧 $[\mathrm{atm}]$

$\chi$; 反応率 $\left[\mathrm{VC} \mathrm{mol} / \mathrm{C}_{2} \mathrm{H}_{2} \mathrm{~mol}\right]$

（2）（3）式の定数項を決定するために表 4, 表 5 の実測値より $r_{0}, r$ および $p_{\Lambda}$ の関係を求めると表 6 扎よび表 7 の結果となる。

表 $6 p_{N} / \sqrt{r_{0}}$ と $p_{\mathrm{A}}$ との関係

\begin{tabular}{rccc}
\multicolumn{1}{c}{$r_{0}$} & $\sqrt{r_{0}}$ & $p_{\mathbf{A}}$ & $\boldsymbol{p}_{\mathbf{A}} / \sqrt{r_{0}} \times 10^{3}$ \\
\hline 590 & 24.29 & 0.10 & 4.11 \\
970 & 31.14 & 0.17 & 5.43 \\
2000 & 44.72 & 0.33 & 7.38 \\
3060 & 55.00 & 0.40 & 7.28 \\
3060 & 55.00 & 0.50 & 9.10
\end{tabular}

表 $7 \sqrt{p_{\mathrm{A}}^{2}-\left(1-2 p_{\mathrm{A}}\right) / \boldsymbol{K}} / \boldsymbol{r}$ と $p_{\mathrm{A}}$ との䦥係

この関係を図示すると図 9 およ。 び図 10 のよ5な直線関係が得ら れ，この勾町と縦軸の載片より各 定数項吕 $a=2.9 \times 10^{-3}, b+c=$ $1.24 \times 10^{-2}, \quad a+d=1.70 \times 10^{-2}$, $(b+c)-2 d=-1.94 \times 10^{-2}$ と決

7) K.H. Yang, O.A. Hougen, Chem. Eng. Prog. 46, 146 (1950); T. E. Corrigan, Chem. Eng. 62, Feb. 195 (1955); 62, Jan. 201 (1955).

8) 三川, 日化 73,79 (1952). 


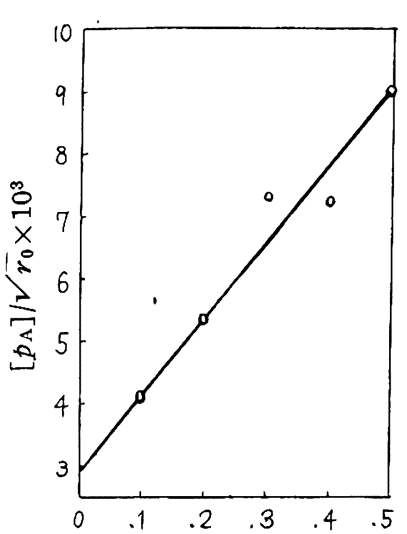

$\left[p_{\mathrm{A}}\right]$

図 $9 \quad\left[p_{\mathrm{A}}\right] / \sqrt{r_{0}} と\left[p_{\mathrm{A}}\right]$ との関倸

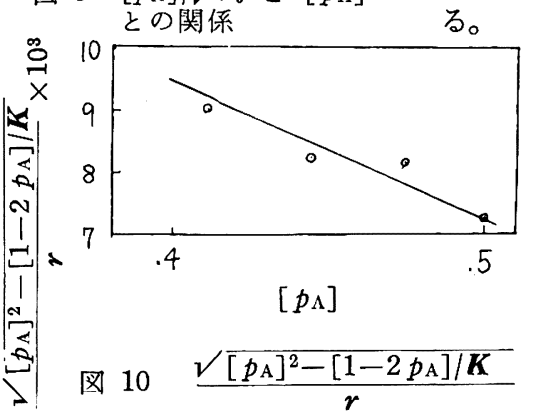

と $\left[p_{\mathrm{A}}\right]$ との関係
定される。したがって（1）式 の VC 合成反応速度式は次のよ らになる。

$$
r \doteqdot p_{\Lambda}{ }^{2} /\left(1.70 \times 10^{-2}\right.
$$$$
\left.-1.94 \times 10^{-2} p_{\mathrm{A}}\right)^{2}
$$

したがって本反応条件に拁け る反応率と反応速度の関係は $r=[(1-\chi) /(2-\chi)]^{2} /[1.70 \times$

$$
10^{-2}-1.94 \times 10^{-2}\{(1-\lambda) \mid
$$$$
(2-\chi)\}]^{2}
$$

で表わされ，定温定圧において 一定組成の原料については, 反 応速度は反応率のみの関数であ る。

\section{（3）実験式の検討} 流通反応系の基本 式昂 $W / F=\int_{0}^{x} d \chi / r \kappa$ 上式 (5) の $r$ を代入 して $\chi$ と $W / F$ を図 式積分し，一定反応率 そおける $W / F$ の実測

\begin{tabular}{|c|c|c|c|c|c|c|c|}
\hline$x$ & $\left(\frac{1-x}{2-x}\right)^{2}$ & $f \times 10^{2}$ & $f^{2} \times 10^{4}$ & $r \times 10^{-3}$ & $1 / r \times 10^{3}$ & $\begin{array}{l}W / F \times 10^{4} \\
\text { (計算值) }\end{array}$ & $\begin{array}{c}W / F \times 10^{4} \\
\text { (実测值) }\end{array}$ \\
\hline 0 & 0.250 & 0.730 & 0.533 & 4.70 & 0.213 & - & - \\
\hline 0.1 & 0.225 & 0.783 & 0.613 & 3.68 & 0.272 & 0.25 & 0.30 \\
\hline 0.2 & 0.197 & 0.840 & 0.706 & 2.79 & 0.359 & 0.56 & 0.60 \\
\hline 0.3 & 0.170 & 0.900 & 0.810 & 2.10 & 0.476 & 0.98 & 0.90 \\
\hline 0.4 & 0.141 & 0.973 & 0.947 & 1.49 & 0.672 & 1.56 & 1.30 \\
\hline 0.5 & 0.111 & 1.053 & 1.103 & 1.00 & 1.000 & 2.40 & 1.80 \\
\hline 0.6 & 0.081 & 1.149 & 1. 323 & 0.61 & 1.64 & 3.70 & 2.30 \\
\hline 0.7 & 0.053 & 1.254 & 1.563 & 0.34 & 2.94 & 6.00 & 3.00 \\
\hline 0.8 & 0.028 & 1. 376 & 1.904 & 0.15 & 6.68 & 10.50 & 4.70 \\
\hline 0.9 & 0.008 & 1.524 & 2.310 & 0.03 & 33.3 & 22.00 & 7.20 \\
\hline
\end{tabular}

表 8 反応率と $W / F$ 関係の実测値と計算値

值と計算值を比較した。その結果は表 8 亿示す。

ただし $f=1.70 \times 10^{-2}-1.94 \times 10^{-2}[(1-\chi) /(2-\chi)]$

表 8 の結果より理論式より出した $W / F$ と実測値とが比較的よ く一致している。

（昭和 33 年 4 月，日化第 11 年会講演）

最後に実験劦力された長沼文雄君および発表を許可された会 社当局の方々に厚く感謝致します。

9) O.A. Hougen, K.M. Watson, "Chemical Process Principles" (John Wiley, 1947); T.E. Corrigan, Chem. Eng. 62, March 197 (1955).

\section{パルプのハイポクロライト漂白に際してセルロースの酸化崩壊 に及ぼすへミセルロースの影響十}

(昭 和 33 年 7 月 14 日 受 理)

\section{越 沢 徳 美*}

ハイポクロライト溶液によるサルファイトパルプの漂白に際してへミセルロースがセルロースの不均一酸化崩壊にどの ような影響を及ぼすかを明らかにするため，脱りグニンパルプより冷アルカリあるいは熱アルカリ処理によっていミセル ロースを段階的に抽出したパルプと，へミセルロースモデル物質としてグルコース拉よびビスコース工場のアルカリ浸清 液より採取したへミセルロースとを一定の条件で $\mathrm{NaClO}$ 漂白し，その挙動を検討した。

ヘミセルロースはセルロースにくらベて $\mathrm{NaClO}$ との応速度が早いために有効塩素を優先的に消費し，木材セルロ一 スの酸化崩壊を抑制し保護的作用を示す。またへミセルロースの抽出方法の差はセルロースの酸化举動にあまり影謷を与 えないので，細胞膜中におけるへミセルロースの分布状態等の形熊学的因子が保護作用に及ぼす影響は比較的少ないと思 われる。 $\mathrm{NaClO}$ に対するセルロースとへミセルロースの accessibility の差異は $\mathrm{ClO}_{2}$ に対するより小さく，したがっ て $\mathrm{ClO}_{2}$ 漂白の場合にくらべてへミセルロースの保護作用が弱いことが認められた。

\section{I. 緒言}

サルフフイトパルプをハイポクロライト溶液で漂白する場合, セルロース随伴物質中のリグニンはセルロースの不均一系酸化崩 壞に対してある程度の保護作用を示す。この現象については前 報1)で詳細に報告したが，パルプ中のセルロース随伴物質として はリグニン以外にへミセルロースが重要な成分であり，このへミ セルロースがパルプの漂白に際して果す役割について，次に当然 考虙しなければならない。また，著者は既報2゙においてパルプの 二酸化塩素漂白に関する研究を発表したが，その際セルロースの

† 本報を「溶解用パルプに関する研究（第 17 報）」とする.

* 與国人綟パルプ株式会社研究部：東京都港区芝田村町.

1) 越沢, 工化 61,1623 (1958).

2) 越沢, 工化 61, 1093 (1958).
酸化崩壊に及ぼすセルロース随伴物質の影響を論じ，リグニンと へミセルロースの影響を㐿列的に検討して，へミセルロース自身 もセルロースの酸化崩買に対して保謢的な役割を有することを確 認している。

そこで本報においては， $\mathrm{NaClO}$ 漂白においてセルロースの酸 化崩壊に及ぼすへミセルロースの影響を単独に検討し，あわせて この観点から $\mathrm{ClO}_{2}$ 漂白との比較を行うため，次のような実験を 行った。

ヘミセルロースの影響にはリグニンと同じように，その分子構 造にもとづく純化学的因子とその細胞膜内の分布状態等にもとづ く形態学的, 微細構造的因子とがあると考えられるので, まず脱 リグニンパルプより抽出方法を種々変えていミセルロースを段階

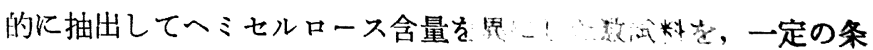

